\title{
FAKTOR YANG BERHUBUNGAN DENGAN PENGGUNAAN KONTRASEPSI SUNTIK 3 BULAN DIWILAYAH PUSKESMAS TAGULANDANG KABUPATEN SITARO
}

\author{
Sriwulan. Karimang ${ }^{1}$, T. D. E. Abeng ${ }^{2}$, Wico N. Silolonga ${ }^{3}$ \\ 1. Mahasiswa Program Studi Ilmu Keperawatan, Fakultas Kedokteran, Univeristas Sam \\ Ratulangi, Indonesia
}

2. IAIN (INSTITUT AGAMA ISLAM NEGERI ) Manado, indonesia

3. Puskesmas Tinoor Tomohon, Indonesia

Email: Sriwulankarimang20@gmail.com

\begin{abstract}
KB injection is a hormonal contraceptive method that contains etherogens. This contraception works by preventing egg release so that there will be no fertilization of the egg by sperm. One injection is given every three months and the injection is very effective if routinely given in a timely manner. Method: This study used a cross sectional study design with a population of all mothers who used 3-month injection contraception in the Tagulandang Health Center, Sitaro District. Sampling was done by non-probability sampling with pruposive sampling technique. The number of samples is 38 respondents. Data is presented in the form of Frequency Tables. Data analysis used is univariate and bivariate analysis using the chi-square analysis method. The results of the study: based on the characteristics showed that most respondents chose the use of 3-month injection contraception, respondents aged 20-35 years received support from husbands with good incomes. From the chi-square test results obtained $\rho$ value for age $\rho=0.02$ less than $\alpha=$ 0.05 , $\rho$ value for husband support $\rho=0.04$ less than $\alpha=0.05, \rho$ value for income $\rho=0.01$ is smaller than $\alpha=0.05$. In conclusion, the results of this study indicate that there is a significant relationship between age, husband support, income and injecting contraceptive use in 3-month injection contraception in the Tagulandang Community Health Center, Sitaro Regency.
\end{abstract}

\section{Keywords: Age, Husband Support, Income.}

Abstrak: Suntik KB 3 bulan adalah metode kontrasepsi hormonal yang mengandung eterogen. Kontrasepsi ini bekerja dengan mencegah pengeluaran sel telur sehinggah tidak akan terjadi pembuahan sel telur oleh sperma. Satu suntikan di berikan setiap tiga bulan dan suntikan tersebut sangat efektif apabila rutin di berikan secara tepat waktu. Metode: Penelitian ini menggunakan desain penelitian cros sectional dengan populasi seluruh ibu yang menggunakan kontrasepsi suntik 3 bulan diwilayah Puskesmas Tagulandang Kabupaten Sitaro. Pengambilan sampel dilakukan secara non probability sampling dengan teknik pruposive sampling. Jumlah sampel sebanyak 38 responden. Data disajikan dalam bentuk Frequency Table, Analisis data yang digunakan adalah analisis univariat dan bivariat dengan menggunakan metode analisis chi-square. Hasil penelitian: Berdasarkan karakteristik menunjukkan sebagian besar responden memilih penggunaan kontrasepsi suntik 3 bulan, responden memiliki usia 20-35 tahun mendapat dukungan dari suami dengan pendapatan yang baik. Dari hasil uji chi-square didapatkan hasil nilai $\rho$ untuk usia $\rho=0,02$ lebih kecil dari $\alpha=$ 0,05 , nilai $\rho$ untuk dukungan suami $\rho=0.04$ lebih kecil dari $\alpha=0,05$, nilai $\rho$ untuk pendapatan $\rho=0,01$ lebih kecil dari $\alpha=0,05$. Kesimpulan, hasil penelitian ini menunjukan ada hubungan yang bermakna antara Usia, Dukungan suami, Pendapatan dengan Penggunaan Kontrasepsi Suntik 3 bulan di Wilayah Puskesmas Tagulandang Kabupaten Sitaro.

Kata Kunci: Usia, Dukungan Suami, Pendapatan. 


\section{PENDAHULUAN}

Suntik KB 3 bulan adalah metode kontrasepsi hormonal yang mengandung eterogen. Kontrasepsi ini bekerja dengan mencegah pengeluaran sel telur sehinggah tidak akan terjadi pembuahan sel telur oleh sperma. Satu suntikan di berikan setiap tiga bulan dan suntikan tersebut sangat efektif apabila rutin di berikan secara tepat waktu (T. Yuniastuti, 2011). Perencanaan KB harus dimiliki oleh setiap keluarga termasuk calon pengantin, misalnya kapan usia ideal untuk melahirkan, berapa jumlah anak, dan jarak kelahiran yang ideal, bagaimana perawatan kehamilan, serta tanda-tanda bahaya dalam kehamilan (Depkes, RI, 2014).

\section{Menurut World Health Organization (WHO) menjelaskan peningkatan} penggunaan kontrasepsi tertinggi adalah di Asia dan Amerika Latin, dan terendah di Sub-Sahara Afrika. Secara global penggunaan kontrasepsi modern telah meningkat sedikit dari 54\% di tahun 1990 menjadi $57 \%$ pada tahun 2015. Di Afrika dari $23,6 \%$ menjadi $28,5 \%$, di Asia telah meningkat sedikit dari $60,9 \%$ menjadi 61,8\%, sedangkan di Amerika Latin dan Karibia tetap stabil pada $66,7 \%$ (WHO, 2015). Indonesia merupakan sebuah Negara berkembang dengan jumlah penduduk sebanyak 252.124.458 jiwa dengan luas wilayah 1.913.378,68 $\mathrm{km}^{2}$ dan kepadatan penduduk sebesar 131,76 jiwa $/ \mathrm{km}^{2}$ (Depkes RI, 2014). Data dari Survei Demografi dan Kesehatan Indonesia (SDKI 2012) menunjukan tren prevalensi penggunaan kontrasepsi atau Contraceptive Prevalence Rate (CRP) di indonesia 1991-2012 cenderung meningkat, sementara tren Angka fertilitas atau Total Fertility Rate (TFR) cenderung menurun. Tren ini menggambarkan bahwa meningkatnya cakupan wanita usia 15-49 tahun yang melakukan KB sejalan dengan menurunnya angka fertilitas nasional. Bila dibandingkan dengan target Rencana Pembangunan Jangka Menengah Daerah (RPJMN) 2014, C-Reaktif Protein CRP telah melampaui target $(60,1 \%)$ dengan capaian $61,9 \%$, namun TRF belum mencapai target $(2,36)$ dengan angka tahun 2012 sebesar 2,6. Data Kependudukan dan Keluarga Berencana Nasional (KKBN) menunjukan bahwa pada tahun 2013 ada 8.500.247 Pasangan Usia Subur (PUS) yang merupakan peserta KB baru, dan hampir separuhnya (48,56\%) menggunakan metode kontrasepsi suntikan. Pada tahun 2013, cakupan KB aktif secara nasional sebesar $75,88 \%$. Dari 33 provinsi, ada 15 provinsi yang cakupannya masih beradah di bawah cakupan nasional. Provinsi bengkulu merupakan provinsi dengan cakupan tinggi sebesar 87,70\%, dan provinsi papua merupakan provinsi dengan cakupan terendah sebesar 67,15\%. Dari data Riskesdas 2013 menunjukan bahwa pada wanita usia 15-49 tahun dengan status kawin sebesar 59,3\% menggunakan metode $\mathrm{KB}$ modern (implan, Metode Operasi Wanita (MOW), Metode Operasi Pria (MOP), Intrauterine Device (IUD), kondom, suntikan pil), 0,4\% menggunakan metode $\mathrm{KB}$ tradisional (menyusui/MAL, pantang berkala/kalender, senggama terputus , lainnya), 24,7\% pernah melakukan KB, $15,5 \%$ tidak pernah melakukan KB.

Pelayanan KB menyediakan informasi, pendidikan, dan cara-cara bagi laki-laki dan perempuan untuk dapat merencanakan kapan akan mempunyai anak, berapa jumlah anak, berapa tahun jarak usia antara anak, serta kapan akan berhenti mempunyai anak. Baik suami maupun istri memiliki hak yang sama untuk menetapkan berapa jumlah anak yang akan dimiliki dan kapan akan memiliki anak. Melalui tahapan konseling pelayanan KB, pasangan usia subur (PUS) dapat menentukan pilihan kontrasepsi sesuai dengan kondisi dan kebutuhannya berdasarkan informasi yang telah mereka pahami, termasuk keuntungan dan kerugian, risiko metode kontrasepsi dari 
petugas kesehatan. (Profil Kesehatan Indonesia, 2015).

Menurut (Kemenkes RI, 2016). Metode kontrasepsi yang paling banyak di gunakan di Sulawesi Utara adalah kontrasepsi suntik sebanyak $39,44 \%$, pil sebanyak $22,54 \%$, implan sebanyak $21,31 \%$, alat kontrasepsi dalam rahim sebanyak 10,32\%, kondom sebanyak $3,64 \%$, metode operasi wanita sebanyak $2,48 \%$ dan metode operasi pria sebanyak $0,28 \%$. Saifuddin, 2013 menyatakan bahwa pada umumnya akseptor lebih memilih metode kontrasepsi suntik 3 bulan karena alasan praktis yaitu sederhana dan tidak perlu takut lupa.

Survei data awal yang dilakukan peneliti terdapat 38 pasien menggunakan kontrasepsi suntik 3 bulan dan metode kontrasepsi yang paling banyak digunakan di wilayah Puskesmas tagulandang kabupaten SITARO pada 3 bulan terakhir mulai dari bulan januari sampai maret 2019 adalah kontrasepsi suntik 3 bulan sebanyak 38 orang, kemudian implant 12 orang, pill ada 12 orang, IUD dan kondom tidak ada pemakai. Kontrasepsi suntik 3 bulan merupakan yang paling banyak digunakan oleh para akseptor KB karena aman, sederhana, efektif dan dapat dipakai pasca persalinan. Diketahui bahwa setiap tahun penggunaan alat kontrasepsi terus meningkat, tidak terkecuali dengan alat kontrasepsi suntik 3 bulan. KB suntik 3 bulan ini yang sangat diminati oleh ibu-ibu adalah alasan peneliti tertarik melakukan penelitian mengenai faktor-faktor yang berhubungan dengan penggunaan kontrasepsi suntik 3 bulan pada akseptor KB di wilayah Puskesmas tagulandang kabupaten SITARO.

\section{METODE PENELITIAN}

Penelitian ini termasuk dalam penelitian kuantitatif dan penelitian ini menggunakan desain penelitian cross sectional. Penelitian ini dilaksanakan diwilayah Puskesmas Tagulandang Kabupaten Sitaro, pada bulan Agustus 2019. Populasi pada penelitian ini adalah semua ibu yang menggunakan kontrasepsi suntik 3 bulan di Puskesmas Tagulandang Kabupaten Sitaro. Dengan jumlah populasi 3 bulan terakhir berjumlah 44 ibu pengguna kontrasepsi suntik 3 bulan. Pengambilan sampel pada penelitian ini dilakukan secara non probability sampling dengan teknik pruposive sampling dengan rumus slovin maka didapatkan jumlah sampel 38 responden. Instrumen yang digunakan dalam penelitian ini menggunakan lembar observasi dan kuesioner. Kuesioner ini terdiri dari 5 pertanyaan tentang dukungan suami yang sudah di teliti sebelumnya oleh (Sitti Afsari, 2017) dan untuk lembar observasi berisikan data umum responden. Analisis Bivariat dalam penelitian ini yaitu untuk mengetahui hubungan antara Usia, dukungan suami dan pendapatan dengan penggunaan kontrasepsi suntik 3 bulan diwilayah Puskesmas Tagulandang Kabupaten Sitaro. Penelitian ini menggunakan uji Chi-square dengan tingkat kepercayaan 95\% $(\alpha=0,05)$. Ketentuan hubungan bermakna jika nilai $\mathrm{p}<0,05$ dan tidak bermakna jika nilai $\mathrm{p}>0,05$.

Penelitian ini telah dilakukan dengan standar Etika Penelitian yaitu : Informed Consent (informasi untuk responden), Anonimity (Tanpa Nama), Confidentiality (Kerahasiaan). Penelitian ini telah diberi izin dengan nomor surat 445/63,1/VIII/2019 oleh Puskesmas Tagulandang Kabupaten Sitaro.

\section{HASIL dan PEMBAHASAN}

\section{Gambaran Umum Tempat Penelitian}

\section{a. Puskesmas Tagulandang}

Puskesmas tagulandang terletak di kelurahan balehumara lingkungan III kecamatan tagulandang kabupaten siau tagulandang biaro. Puskesmas tagulandang adalah unit pelaksana teknis dinas (UPTD) kesahatan kabupaten kepulauan siau tagulandang biaro (sitaro) dengan wilayah kerja secara khusus di kecamatan tagulandang. Jumlah penduduk di wilayah kerja puskesmas tagulandang berjumlah 
12.344 jiwa dan Ada beberapa tempat pelayanan kesehatan yaitu terdiri dari : 4 puskesmas pembantu (pustu), 5 poskesdas,
19 posyandu, 1 posyandu cerdas, 8 posyandu

\section{Karakteristik Responden}

Tabel 1 Distribusi Responden Berdasarkan Pendidikan

\begin{tabular}{ccc}
\hline Pendidikan Terakhir & n & \% \\
\hline SD & 4 & 10,5 \\
SMP & 11 & 28,9 \\
SMA & 17 & 44,7 \\
S1 & 6 & 15,8 \\
\hline Total & $\mathbf{3 8}$ & $\mathbf{1 0 0 , 0}$ \\
\hline
\end{tabular}

Sumber : Data Primer, 2019

Hasil penelitian menunjukan bahwa dari 38 responden sebagian besar berpendidikan SMA sebanyak $17(44,7 \%)$ responden. Hal ini menunjukan seseorang akan berpengaruh dalam memberi respon terhadap sesuatu yang datang dari luar. orang yang berpendidikan tinggi akan memberikan respon yang lebih rasional terhadap stimulus yang diterimanya dan akan berfikir sejauh mana keuntungan yang mungkin akan memperoleh dari gagasan tersebut sedangkan seorang ibu yang memiliki tingkat pendidikan rendah akan lebih sulit menerima informasi yang diberikan.

Dari hasil penelitian tersebut dilihat bahwa di Puskesmas tagulandang kabupaten sitaro menunjukan tingkat pendidikan paling banyak adalah pendidikan SMA. Tingkat pendidikan adalah salah satu faktor yang sangat menentukan pengetahuan dan persepsi seseorang terhadap pentingnya sesuatu hal, termasuknya pemilhan kontrasepsi. Hal ini disebabkan seseorang yang berpendidikan tinggi akan lebih luas pandangannya dan lebih muda menerimah ide/gagasan yang baru sehingga dapat di simpulkan bahwa seharusnya orang yang memiliki tingkat pendidikan yang lebih tinggi akan memilih jenis kontrasepsi MKJP (Kurniawan.T, 2016). Tinggi rendahnya tingkat sosial ekonomi yang dimiliki oleh responden, membuat responden sangat susah untuk membiayai atau melanjutkan pendidikannya, disatu sisi pemenuhan kebutuhan sehari-hari sangat penting untuk dipenuhi.

Table 2 Distribusi Responden Berdasarkan Pekerjaan

\begin{tabular}{ccc}
\hline Pekerjaan & n & \% \\
\hline Honorer & 5 & 13,2 \\
IRT & 23 & 60,5 \\
PNS & 7 & 18,4 \\
Swasta & 3 & 7,9 \\
\hline Total & $\mathbf{3 8}$ & $\mathbf{1 0 0 , 0}$ \\
\hline
\end{tabular}

Sumber : Data Primer, 2019

Hasil penelitian menunjukan bahwa dari 38 responden sebagian besar bekerja sebagai ibu rumah tanggah (IRT) sebanyak $23(60,5 \%)$ responden. Pekerjaan adalah kebutuhan yang harus dilakukan terutama untuk menunjang kehidupannya dan kehidupan keluarga. Bekerja umumnya merupakan kegiatan yang menyita waktu 
serta dapat memberikan pengalaman dan pengetahuan baik secara langsung maupun tidak langsung. Lingkungan pekerjaan dapat membentuk suatu pengetahuan karena adanya saling bertukar informasi antara satu sama lainnya (Wawan dan Dewi, 2010). Dari hasil penelitian tersebut dilihat bahwa di Puskesmas tagulandang kabupaten sitaro menunjukan tingkat pendidikan paling banyak adalah ibu rumah tanggah (IRT). Didalam mendapatkan informasi khususnya mengetahuan tentang KB akan berpengaruh karena biasanya akan didapatkan dilingkungan kerja.

\section{Analisis Univariat}

Table 3 Distribus Responden Berdasarkan Usia

\begin{tabular}{ccc}
\hline Usia & n & \% \\
\hline$<20$ Tahun & 9 & 23,7 \\
20-35 Tahun & 15 & 39,5 \\
$>35$ Tahun & 14 & 36,8 \\
\hline Total & $\mathbf{3 8}$ & $\mathbf{1 0 0 , 0}$ \\
\hline
\end{tabular}

Sumber : Data Primer, 2019

Hasil penelitian menunjukan frekuensi berdasarkan usia di Puskesmas tagulandang kabupaten sitaro yaitu dari 38 responden didapati sebagian responden berusia 20-35 tahun dengan jumlah 15 responden dengan penggunaan kontraepsi Suntik 3 bulan selama $>2$ tahun sebanyak 22 responden. Hasil penelitian ini menunjukan bahwa usia ibu 20-35 tahun itu di sebut idel bagi seorang wanita atau bisa dikatakan kehamilan paling ideal.

Dari hasil penelitian tersebut memperlihatkan bahwa penggunaan kontrasepsi suntik 3 bulan di Puskesmas tagulandang kabupaten sitaro banyak yang berusia 20-35 tahun bertujuan untuk menjarangkan kehamilan. Usia yang terbaik bagi seorang wanita adalah 20-30 tahun karena pada masa inilah alat reproduksi wanita sudah siap dan cukup matang untuk mengandung dan melahirkan anak. Bila ditinjau pola dasar penggunaan kontrasepsi yang rasional maka masa mencegah kehamilan $(<20$ tahun $)$ dianjurkan untuk menggunakan kontrasepsi dengan urutan yang disarankan pil KB, AKDR/IUD, dan Kondom sedangkan pada masa menjarangkan kehamilan (20-30 tahun) dianjurkan untuk menggunakan kontrasepsi dengan urutan AKDR/IUD, pil KB, Suntikan, Implant/susuk, Kondom. Pada masa mengakhiri kehamilan (>35 tahun) dianjurkan untuk menggunakan kontrasepsi dengan urutan AKDR/IUD, Implant, Suntik, pil KB dan Kondom. Dengan demikian umur akan menentukan pemilihan jenis kontrasepsi yang digunakan (Kurniawan.T, 2016).

Tabel 4 Distribusi Responden Berdasarkan Dukungan suami

\begin{tabular}{ccc}
\hline Dukungan Suami & n & \% \\
\hline Mendukung & 21 & 55,3 \\
Tidak Mendukung & 17 & 44,7 \\
\hline Total & $\mathbf{3 8}$ & $\mathbf{1 0 0 , 0}$ \\
\hline
\end{tabular}

Sumber : Data Primer, 2019

Hasil penelitian menunjukkan bahwa sebagian besar responden mendapat dukungan dari suami berjumlah 21 responden dengan penggunaan kontrasepsi 
suntik 3 bulan selama 1 tahun atau $<=2$ tahun sebanyak 13 responden. Kesepakatan antara suami dan istri dalam penggunaan metode kontrasepsi, dalam hal ini suntik sangat diperlukan. Adanya kesepakatan antara keduanya mengenai kontrasepsi yang dipakai oleh suami/istri menyebabkan pemakaian alat kontrasepsi dapat berlangsung secara terus menerus yang merupakan usaha penurunan tingkat fertilitas.

Menurut istri bahwa alasan suami untuk memberikan dukungan adalah agar istri tidak cepat punya anak lagi atau dapat menjarangkan kehamilan. Karena jika punya banyak anak sulit untuk dipenuhi kebutuhannya apalagi kondisi ekonomi keluarga sangat rendah. Responden yang tidak mendapatkan dukungan dari suami menggunakan alat kontrasepsi dikarenakan suami lebih menginginkan jumlah anak yang banyak dengan anak banyak maka dapat membantu orang tua dalam mencari uang selain itu masih adanya pemahaman banyak anak banyak rezeki. Sedangkan responden yang mendapatkan dukungan dari suami dalam menggunakan alat kontrasepsi dikarenakan antara suami dan istri lebih menginginkan suatu keluarga yang ideal (2 anak) dan apabila mempunyai anak banyak, maka nantinya akan susah untuk membiayai kebutuhan anak disetiap tahap perkembangannya serta tidak sesuai dengan tingkat pendapatan atau penghasilan orang tua (Rizali.I.M,2013).

Tabel 5 Distribusi Responden Berdasarkan Pendapatan

\begin{tabular}{ccc}
\hline Pendapatan & n & \% \\
\hline Baik & 20 & 52,6 \\
Cukup Baik & 18 & 47,4 \\
\hline Total & $\mathbf{5 2}$ & $\mathbf{1 0 0 , 0}$
\end{tabular}

Sumber : Data Primer, 2019

Hasil penelitian ini dapat dilihat bahwa sebagian besar responden berpendapatan baik yaitu Rp. 500.000 sampai Rp. 2.002.625,-/ bulan atau (> Rp. 2.002.625,-/ bulan) berjumlah 20 responden dengan dengan penggunaan kontrasepsi suntik 3 bulan selama 1 tahun atau $<=2$ tahun sebanyak 12 responden. Dilihat dari hasil tersebeut keluarga yang berpendapatan Baik di puskesmas tagulandang kabupaten sitaro adalah sebanyak 12 responden $(60,0 \%)$ dengan jumlah pendapatan (> Rp. 2.002.625,-/ bulan.

Hal ini dapat dipengaruhi oleh karakteristik dan jumlah responden dari tiap penelitian. Penghasilan mempunyai hubungan erat dengan pemilihan kontrasepsi, responden yang status ekonominya cukup lebih banyak memilih metode kontrasepsi jangka panjang, karena metode tersebut tergolong kontrasepsi yang mahal. Tinggi rendahnya status sosial ekonomi masyarakat mempengaruhi pemilihan jenis kontrasepsi karena dari tingkat ekonomi masyarakat berkaitan erat dengan kemampuan untuk membeli alat kontrasepsi yang akan digunakan misalnya keluarga yang berpenghasilan cukup akan lebih mampu mengikuti program KB dari pada keluarga yang tidak mampu, karena bagi keluarga yang kurang mampu KB bukanlah merupakan kebutuhan pokok (Wa Ode.D.A, 2013). 
Tabel 5.6 Distribusi Responden Berdasarkan Penggunaan Kontrasepsi Suntik 3 bulan

\begin{tabular}{ccc}
\hline $\begin{array}{c}\text { Penggunaan Kontrasepsi Suntik 3 } \\
\text { bulan }\end{array}$ & n & \% \\
\hline$<=2$ tahun & 16 & 42,1 \\
$>2$ tahun & 22 & 57,9 \\
\hline Total & $\mathbf{3 8}$ & $\mathbf{1 0 0 , 0}$ \\
\hline Sumber : Data Primer, 2019 & &
\end{tabular}

Hasil penelitian ini dapat dilihat bahwa sebagian besar responden pengguna kontrasepsi suntik 3 bulan dalam jangka waktu pemakaian selama $>2$ tahun sebanyak 22 responden. Dilihat dari hasil tersebut maka penggunaan kontrasepsi suntik 3 bulan terbanyak untuk pemakaian $>2$ tahun atau 2 tahun di wilayah Puskesmas tagulandang kabupaten sitaro. Suntik KB 3 bulan adalah metode kontrasepsi hormonal yang mengandung hormon progestin, namun tidak mengandung esterogen. Kontrasepsi ini bekerja dengan mencegah pengeluaran sel telur sehingga tidak akan terjadi pembuahan sel telur oleh sperma. Satu suntikan di berikan tiap tiga bulan dan suntikan tersebut sangat efektif apabila rutin di berikan secara tepat waktu.

Menurut Sperrof. L (2005) mengatakan bahwa terdapat hormon progesteron yang

\section{Analisis Bivariat}

terkandung dalam kontrasepi suntik menyebabkan penebalan mukusserviks dan perubahan pada endometrium. Akibat dari kadar progesteron dalam sirkulasi cukup tinggi dan menghambat lonjakan LH secara efektif sehingga tidak terjadi menstruasi atau amenorrhoe. Oleh karena itu . Pada pemakaian $\geq 15$ bulan dimana proses menstruasi telah terhenti, akseptor diharapkan untuk menggati alat kontrasepsinya dengan kontrasepsi mantap non hormonal sebagai penanggulangan keresahan akseptor dalam menghadapi keadaan tidak haid akibat kontrasepsi suntik 3 bulan (Arum dan Sujiyatini, 2011). Pengguna KB suntik 3 bulan jenis DMPA memiliki resiko 2 kali lipat dibandingkan penggunaan jenis lainnya untuk mengalami obesitas selama 3 tahun pemakaian.

Tabel 6 Hubungan Usia dengan Penggunaan Kontrasepsi Suntik 3 Bulan

\begin{tabular}{|c|c|c|c|c|c|c|c|}
\hline \multirow{3}{*}{ Usia } & \multicolumn{4}{|c|}{$\begin{array}{c}\text { Penggunaan Kontrasepsi Suntik } 3 \\
\text { Bulan }\end{array}$} & \multirow{2}{*}{\multicolumn{2}{|c|}{ Total }} & \multirow[t]{3}{*}{$\boldsymbol{\rho}$} \\
\hline & \multicolumn{2}{|c|}{$<=2$ tahun } & \multicolumn{2}{|c|}{$>2$ tahun } & & & \\
\hline & $\mathbf{n}$ & $\%$ & $\mathbf{n}$ & $\%$ & $\mathbf{n}$ & $\%$ & \\
\hline$<20$ Tahun & 6 & 66,7 & 3 & 33,3 & 9 & 100 & \\
\hline 20-35 Tahun & 8 & 53,3 & 7 & 46,7 & 15 & 100 & 0,02 \\
\hline$>35$ Tahun & 2 & 57,9 & 12 & 42,1 & 14 & 100 & \\
\hline Total & 16 & 42,1 & 22 & 57,9 & 38 & 100 & \\
\hline
\end{tabular}

Sumber : Data Primer, 2019

Hasil uji hipotesa dari usia dengan penggunaan kontrasepsi suntik 3 bulan menggunakan uji Chi-square pada tingkat kemaknaan $95 \%(\alpha=0,05)$, menunjukan adanya hubungan yang signifikan antara usia dengan penggunaan kontrasepsi suntik 3 bulan di wilayah Puskesmas tagulandang kabupaten sitaro. Dimana nilai $\mathrm{p}$-value $=$ 
0,02 lebih kecil dari $\alpha=0,05$. Hal ini sejalan dengan penelitian yang dilakukan Anita yang mengatakan adanya hubungan atau pengaruh antara usia tehadap penggunaan kontrasepsi suntik 3 bulan (Supriadi,2017). Usia hubungannya dengan pemakaian kontrasepsi suntik 3 bulan berperan sebagai faktor intrinsik. Usia berhubungan dengan struktur organ, komposisi biokimiawi termasuk sistem hormonal seorang wanita. Perbedaan komposisi biokimiawi, dan sistem hormonal pada suatu periode usia menyebabkan perbedaan pada kontrasepsi yang dibutuhkan (Lontaan, 2014, dalam Supriadi, 2017).

Hasil penelitian yang peneliti dapatkan menggunakan lembar observasi pada usia didapatkan sebagian besar ibu yang berusia 20-35 tahun berjumlah 15 responden dengan penggunaan kontrasepsi suntik 3 bulan dalam jangka waktu pemakaian selama 1 tahun atau $<=2$ tahun sebanyak 8 responden. Untuk responden dengan penggunaan kontrasepsi suntik 3 bulan dalam jangka waktu pemakain selam 2 tahun atau $>2$ tahun berusia 20-35 tahun sebanyak 7 responden. Seperti penelitian (Notoatmodjo, 2010, Rizali, 2013 dalam Supriadi, 2017) mengatakan usia merupakan hal yang sangat berperan dalam penentuan untuk menggunakan alat kontrasepsi karena pada fase-fase tertentu dari usia menentukan tingkat reproduksi seseorang. Usia yang terbaik bagi seorang wanita adalah antara 20-30 tahun karena pada masa inilah alat-alat reproduksi wanita sudah siap dan cukup matang untuk mengandung dan melahirkan anak. Bila ditinjau pola dasar penggunaan alat kontrasepsi yang rasional maka masa mencegah kehamilan (< 20 tahun) dianjurkan untuk menggunakan kontrasepsi dengan urutan yang disarankan Pil KB, AKDR/IUD dan Kondom. Sedangkan pada masa menjarangkan kehamilan (20-30 tahun) dianjurkan untuk menggunakan kontrasepsi dengan urutan AKDR/IUD, pil KB, Suntikan, Implant/susuk, Kondom dan kontap. Pada masa mengakhiri kehamilan ( $>30$ tahun) dianjurkan untuk menggunakan kontrasepsi dengan urutan kontap, AKDR/IUD, Implant, Suntik, pil KB, dan kondom. Maka dari hasil tersebut dapat di lihat bahwa paling banyak ibu yang memilih kontrasepsi suntik 3 bulan yaitu kontrasepsi suntik yang berusia 20-35 tahun dengan alasan karena usia seseorang akan mempengaruhi penggunaan alat kontrasepsi yang merupakan alat yang baik digunakan untuk menjarangkan kehamilan. Mereka yang usia 20-35 tahun mampu mengetahui urutan-urutan pemilihan alat kontrasepsi yang akan digunakan sesuai dengan fase-fase yang ditentukan.

Dari hasil yang peneliti dapatkan sebagian berjumlah 9 responden berusia $<20$ tahun dengan penggunaan kontrasepsi suntik 3 bulan dalam jangka waktu pemakaian selama 1 tahun atau $<=2$ tahun. Sedangkan pada pemakaian dalam jangka waktu selama 2 tahun atau $>2$ tahun terdapat 3 responden dengan penggunaan kontrasepsi suntik 3 bulan.

Bila ditinjau pola dasar penggunaan kontrasepsi yang rasional maka masa mencegah kehamilan $(<20$ tahun $)$ dianjurkan untuk menggunakan kontrasepsi dengan urutan yang disarankan pil KB, AKDR/IUD, karena usia <20 tahun sangat berisiko dalam kehamilan di sebabkan oleh janin dalam usia tersebut masih sangatlah lemah. Hal ini juga peneliti dapatkan ada beberapa responden dengan jumlah 14 responden berusia $>35$ tahun dengan penggunaan kontrasepsi suntik 3 bulan dalam jangka waktu pemakaian selama 1 tahun atau $<=2$ tahun ada 3 responden sedangkan untuk pengguna dalam jangka waktu selama 2 tahun atau $>2$ tahun sebanyak 12 responden dengan penggunaan kontrasepsi suntik 3 bulan. Menurut penelitian (Saifuddin, 2010) Wanita yang usianya berada di antara 30 - 40 tahunan berisiko untuk mengalami beberapa masalah seperti melahirkan bayi dengan syndroma down, kecenderungan untuk melahirkan dengan 
seksio Cesarean, masalah-masalah dengan diabetes dan tekanan darah tinggi, serta persalinan yang lebih sulit dan lama. Selain itu, sebagian masalah kesehatan adalah berkaitan dengan usia dan risiko mengalami masalah kesehatan akan meningkat sejalan dengan penigkatan usia.

Hal ini sejalan dengan penelitian yang dilakukan oleh Junita yang mengatakan tidak ada pengaruh umur terhadap pemakaian alat kontrasepsi suntik 3 bulan (Junita, 2009). Namun hal ini tidak sejalan dengan penelitian yang dilakukan Anita yang mengatakan adanya hubungan atau pengaruh antara umur tehadap penggunaan kontrasepsi suntik 3 bulan (Anita, 2014) Penelitian yang sama dilakukan oleh Pramono dan Ulfa (2012) di Semarang dimana pada penelitiannya disebutkan bahwa ada hubungan antara umur dengan penggunaan kontrasepsi suntik 3 bulan.

Tabel 7 Hubungan Dukungan Suami dengan Penggunaan Kontrasepsi Suntik 3 Bulan

\begin{tabular}{|c|c|c|c|c|c|c|c|}
\hline \multirow[t]{3}{*}{ Dukungan Suami } & \multicolumn{4}{|c|}{$\begin{array}{c}\text { Penggunaan Kontrasepsi Suntik } 3 \\
\text { bulan }\end{array}$} & \multicolumn{2}{|c|}{ Total } & \multirow[t]{3}{*}{$\rho$} \\
\hline & \multicolumn{2}{|c|}{$<=2$ tahun } & \multicolumn{2}{|c|}{$>2$ tahun } & \multirow[b]{2}{*}{$\mathbf{n}$} & \multirow[b]{2}{*}{$\%$} & \\
\hline & $\mathbf{n}$ & $\%$ & n & $\%$ & & & \\
\hline Mendukung & 13 & 61,9 & 8 & 38,1 & 21 & 100 & 0,01 \\
\hline Tidak Mendukung & 3 & 17,6 & 14 & 82,4 & 17 & 100 & \\
\hline Total & 16 & 42,1 & 19 & 57,9 & 38 & 100 & \\
\hline
\end{tabular}

Sumber : Data Primer, 2019

Hasil uji hipotesa dari dukungan suami dengan penggunaan kontrasepsi suntik 3 bulan menggunakan uji Chi-square pada tingkat kemaknaan 95\% $(\alpha=0,05)$, menunjukan adanya hubungan yang signifikan antara dari dukungan suami dengan penggunaan kontrasepsi suntik 3 bulan di wilayah Puskesmas tagulandang kabupaten sitaro. Dimana nilai $\mathrm{p}$-value $=$ 0,01 lebih kecil dari $\alpha=0,05$. Hal ini sejalan dengan penelitian yang dilakukan oleh Anita yang mengatakan ada hubungan antara partisipasi suami/isteri dengan pemilihan kontrasepsi (Anita, 2014). Program KB dapat terwujud dengan baik bila ada dukungan dari pihak tertentu.

Hasil penelitian yang peneliti dapatkan menggunakan lembar kuesioner dukungan suami didapatkan sebagian besar ibu yang mendapat dukungan suami terhadap penggunaa kontrasepsi suntik 3 bulan berjumlah 21 responden. Responden yang mendapat dukungan dari suami dengan penggunaan kontrasepsi suntik 3 bulan selama 1 tahun atau $<=2$ tahun sebanyak
13 responden. Dalam penggunaan kontrasepsi merupakan tanggung jawab bersama pria dan wanita sebagai pasangan, sehingga metode kontrasepsi yang dipilih mencerminkan kebutuhan serta keinginan suami dan istri. Suami dan istri harus saling mendukung dalam penggunaan kontrasepsi karena keluarga berencana dan kesehatan reproduksi bukan hanya tanggung jawab pria atau wanita saja. Meskipun responden yang mendapat dukungan suami namun masih ada beberapa responden yang tidak mendapat dukungan suami berjumlah 17 responden dengan penggunaan kontrasepsi suntik 3 bulan selama 2 tahun atau $>2$ tahun. Hal ini di karenakan responden memiliki pendapatan cukup. Seperti penelitian dari Hartanto (2010) mengatakan bahwa pendapatan sangat berpengaruh dalam pemilihan atau penggunaan kontrasepsi suntik dan metode kontrasepsi tidak dapat dipakai istri tampa kerjasama suami dan saling percaya. Keadaan ideal bahwa pasangan suami istri harus bersama memilih metode kontrasepsi yang terbaik, 
saling kerja sama dalam pemakaina, membiayai pemakaian kontrasepsi, dan memperhatikan efek pada pemakaiannya. Dukungan suami terhadap pemilihan kontrasepsi suntik akan berpengaruh terhadap penggunaan kontrasepsi suntik 3 bulan oleh istri. Responden yang mendapatkan dukungan dari suami dalam menggunakan alat kontrasepsi dikarenakan antara suami dan istri lebih menginginkan suatu keluarga yang ideal (2 anak) dan apabila mempunyai anak banyak, maka nantinya akan susah untuk membiayai kebutuhan anak disetiap tahap perkembangannya serta tidak sesuai dengan tingkat pendapatan atau penghasilan orang tua.

Dari hasil yang peneliti dapatkan terdapat 17 responden yang tidak mendapat dukungan suami terhadap penggunaan kontrasepsi suntik 3 bulan. Responden yang tidak mendapat dukungan suami sebanyak 3 responden dengan penggunaan kontrasepsi suntik 3 bulan dalam jangka waktu pemakaian selama 1 tahun atau $<=2$ tahun. Meskipun responden tidak mendapat dukungan dari suami namun ada beberapa responden yang mendapat dukungan suami sebanyak 8 responden dengan penggunaan kontrasepsi suntik 3 bulan dalam jangka waktu pemakaian selama 2 tahun atau $>2$ tahun. Responden yang tidak mendapatkan dukungan dari suami menggunakan alat kontrasepsi dikarenakan suami lebih menginginkan jumlah anak yang banyak dengan anak banyak maka dapat membantu orang tua dalam mencari uang selain itu masih adanya pemahaman banyak anak banyak rezeki. Dalam keluarga suami mempunyai peranan penting yakni sebagai kepala keluarga. Suami mempunyai hak untuk setuju ataupun tidak setuju dengan apa yang dilakukan istri. Kecuali jika sang istri memberikan penjelasan atau alasan yang tepat mengenai apa yang dilakukannya sehingga suami mengerti.

Hasil penelitian ini sejalan dengan (Anita Hanna, 2012) ikatan suami-istri sangat membantu ketika menghadapi masalah. Karena satu sama lain sangat membutuhkan dukungan dari pasangannya. Dukungan tersebut akan tercipta dengan baik apabila keduabelah pihak mempunyai dukungan interpersonal yang baik. sebagian besar mendapat dukungan suami karena suami masih ingin memiliki dengan jenis kelamin yang berbeda dengan anak yang dimilikinya. Walaupun jumlah anak yang dimiliki sudah cukup besar, jika belum memperoleh anak dengan jenis kelamin yang diinginkan, maka mereka masih akan tetap menunda pemakaian untuk memperoleh keturunan. Menurut istri bahwa alasan suami untuk memberikan dukungan adalah agar istri tidak cepat punya anak lagi atau dapat menjarangkan kehamilan. Karena jika punya banyak anak sulit untuk dipenuhi kebutuhannya apalagi kondisi ekonomi keluarga sangat rendah.

Tabel 7 Hubungan Pendapatan dengan Penggunaan Kontrasepsi Suntik 3 Bulan

\begin{tabular}{|c|c|c|c|c|c|c|c|}
\hline \multirow{3}{*}{ Pendapatan } & \multicolumn{4}{|c|}{$\begin{array}{c}\text { Penggunaan Kontrasepsi Suntik } 3 \\
\text { bulan }\end{array}$} & \multicolumn{2}{|c|}{ Total } & \multirow[t]{3}{*}{$\rho$} \\
\hline & \multicolumn{2}{|c|}{$<=2$ tahun } & \multicolumn{2}{|c|}{$>2$ tahun } & \multirow[b]{2}{*}{$\mathbf{n}$} & \multirow[b]{2}{*}{$\%$} & \\
\hline & $\mathbf{n}$ & $\%$ & $\mathbf{n}$ & $\%$ & & & \\
\hline Baik & 12 & 60,0 & 8 & 40.0 & 20 & 100 & 0,04 \\
\hline Cukup & 4 & 22,2 & 14 & 77,8 & 18 & 100 & \\
\hline Total & 16 & 42,1 & 22 & 57,9 & 38 & 100 & \\
\hline
\end{tabular}

Sumber : Data Primer, 2019 
Hasil uji hipotesa dari pendapatan dengan penggunaan kontrasepsi suntik 3 bulan menggunakan uji Chi-square pada tingkat kemaknaan 95\% $(\alpha=0,05)$, menunjukan adanya hubungan yang signifikan antara pendapatan dengan penggunaan kontrasepsi suntik 3 bulan di wilayah Puskesmas tagulandang kabupaten sitaro. Dimana nilai $\mathrm{p}$-value $=0,04$ lebih kecil dari $\alpha=0,05$. Hal ini sejalan dengan penelitian (Nazir, 2010:17) mengatakan bahwa setiap individu memiliki penghasilan yang berbeda. Penghasilan yang diterima oleh masyarakat tentu berbeda antara yang satu dengan yang lainnya, hal ini disebabkan bedanya jenis pekerjaan yang dilakukannya. Jenis masyarakat beragam ragam, seperti bertani, nelayan, beternak, buruh serta berdagang dan juga bekerja pada sektor pemerintahan dan swasta.

Hasil penelitian yang peneliti dapatkan menggunakan lembar observasi pendapatan didapatkan sebagian besar ibu yang mempunyai pendapatan yang baik berjumlah 20 responden dengan penggunaan kontrasepsi suntik 3 bulan. Responden yang berpendapatan baik dengan penggunaan kontrasepsi suntik 3 bulan dalam jangka waktu pemakaian selama 1 tahun atau $<=2$ tahun sebanyak 12 responden. Penelitian ini sejalan dengan penelitian yang dilakukan oleh (Wa Ode.D.A, 2013) yang menunjukan adanya hubungan antara biaya kontrasepsi dengan penggunaan kontrasepsi suntik 3 bulan. Pendapatan suatu keluarga berhubungan erat dengan kebutuhan-kebutuhan keluarga. Penghasilan seseorang merupakan salah satu faktor yang mempengaruhi penerimaan dan pengambilan keputusan terhadap inovasi baru. Hasil penelitian menunjukan bahwa responden menggunakan kontrasepsi suntik lebih banyak yang berpendapatan Tinggi. Hal ini menunjukan bahwa keinginan Pasutri (pasangan suami istri) untuk menjadi aksepstor KB atau dalam pemilihan kontrasepsi suntik 3 bulan masih peduli dengan penggunaan kontrasepsi suntik dan ada juga sebagian aksepstor yang berpendapatan Rendah meskipun pendapatan mereka tergolong rendah karena dilihat dari segi biaya, kontrasepsi suntik yang digunakan cenderung lebih murah dibanding dengan kontrasepsi lainnya. Meskipun responden yang mempunyai pendapatan baik namun ada beberapa responden yang berpendapatan cukup sebanyak 14 responden dengan penggunaan kontrasepsi suntik 3 bulan dalam jangka waktu pemakaian selama 2 tahun atau $>2$ tahun. Pendapatan yang cukup ini mempengaruhi ibu lebih mudah memilih alat kontrasepsi, salah satunya alat kontrasepsi suntik sedangkan responden yang berpendapatan cukup dengan alasan karena terbatas dalam memenuhi kebutuhan apalagi responden mempunyai anak lebih dari 1 atau 2 orang, dalam mempunyai anak lebih tidaklah mudah untuk memenuhi kebutuhannya, semakin banyak pengeluaran semakin terbatas dalam penggunaan kontrasepsi.

Dari hasil yang peneliti dapatkan berjumlah 18 responden yang berpendapatan cukup sebanyak 4 responden dengan penggunaan kontrasepsi suntik 3 bulan. Responden yang pendapatannya cukup dengan penggunaan kontrasepsi suntik 3 bulan dalam jangka waktu pemakaian selama 1 tahun atau $<=2$ tahun. Meskipun responden berpendapatan cukup namun ada beberapa responden yang mempunyai pendapatan baik sabanyak 8 responden dengan penggunaan kontrasepsi suntik 3 bulan 3 bulan dalam jangka waktu pemakaian selama 2 tahun atau >2 tahun. Responden yang berpendapatan baik karena penghasilan yang diperoleh ditentukan oleh pekerjaan akseptor KB. Ibu yang bekerja secara tidak langsung membantu perekonomian keluarga sehingga pendapatan keluarga meningkat. Hal ini dapat diasumsikan bahwa semakin tinggi pendapatan rata-rata keluarga perbulan maka daya beli responden akan kontrasepsi akan semakin besar pula. 
Penelitian ini sejalan dengan penelitian yang dilakukan oleh (Maiharti, 2012 dalam Wa Ode. D.A, 2013) dimana didapat hubungan antara pendapatan keluarga dengan penggunaan metode kontrasepsi suntik $(\mathrm{p}=0,000)$. Hasil penelitian menunjukan ada hubungan yang bermakna antara biaya alat kontrasepsi dengan penggunaan kontrasepsi suntik 3 bulan Adapun besar kekuatan hubungan adalah sedang. Dengan adanya hubungan maka dapat dikatakan bahwa biaya yang dikeluarkan untuk alat kontrasepsi berhubungan dengan penggunaan jenis kontrasepsi yang digunakan, dimana biaya alat kontrasepsi suntik 3 bulan (hormonal) cenderung lebih murah dibanding dengan kontrasepsi lainnya (non hormonal) Terbukti dari hasil analisis dapat dilihat bahwa lebih banyak responden yang menyatakan biaya alat kontrasepsi hormonal murah, dan lebih banyak juga yang menyatakan bahwa alat kontrasepsi non hormonal mahal. Sementara itu dari hasil analisis juga dapat dilihat bahwa sebanyak 12 dari 38 responden yang menggunakan kontrasepsi suntik 3 bulan adalah responden yang berpendapatan tinggi dan yang berpendapatan Cukup sebanyak 14 responden dengan penggunaan kontrasepsi suntik dalam jangka waktu pemakaian selama 2 tahun atau $>2$ tahun. Artinya biaya alat kontrasepsi juga dipengaruhi oleh pendapatan keluarga.

\section{SIMPULAN}

Bagi Tenaga Kesehatan

Bagi tenaga kesehatan, diharapkan dapat memberikan informasi dan sebagai masukan agar dapat terus melakukan penyuluhan kepada ibu-ibu akseptor $\mathrm{KB}$ agar pengetahuannya tentang kontrasepsi berkembang.

Bagi Peneliti Selanjutnya

Diharapkan bagi peneliti selanjutnya hendaknya menggunakan metode penelitian yang lebih baik dan berbeda (desain, sampling), serta dapat menghubungkan variabel penelitian yang lainnya, misalnya efek samping dan dukungan tenaga kesehatan dengan penggunaan kontrasepsi suntik 3 bulan.

\section{DAFTAR PUSTAKA}

Anita Hanna , Djoko Nugroho , Sri Winarni, Hubungan beberapa faktor akseptor dengan pemilihan alat kontrasepsi suntik pada wanita pus keluarga, JURNAL KESEHATAN MASYARAKAT, Volume 1, Nomor 2, Tahun 2012, Halaman 133 - 142 Online di http://ejournals1.undip.ac.id/inde x.php/jkm.

Depkes, RI. 2014. Profil Kesehatan Tahun $2015 . \quad$ www.depkes.go.id/. resources /...kesehatanindonesia/profil-kesehatanIndonesia2014.pdf.(Diakses tanggal 20 April 2017).

Junita. (2009). Faktor-faktor yang mempengaruhi Pemakaian Alat Kontrasepsi pada Istri PUS di Kecamatan Rambah Jamo, Kabupaten Rokan Hulu tahun $2009 . \quad$ Thesis. (http://repository.usu.ac.id.)

Hartanto, H. 2010. Keluarga Berencana Dan Kontrasepsi, Jakarta, Pustaka Sinar Harapan.

Kementerian Kesehatan RI. Kesehatan dalam Kerangka Sistainable Development Goals (SDG'S). Jakarta: Kementerian Kesehatan RI; 2016.

Kurniawan, Tafik. Faktor-faktor yang Mempengaruhi Pemilihan Alat Kontrasepsi Suntik. Skripsi : REFERENSI/16200-48408-1PB.pdf ; 2016.

Nazir, (2010). “Analisis Determinan Pendapatan di Kabupaten Aceh 
Utara". Tesis. Medan. Jurnal management Universitas Sumatera Utara.

Muhammad Irwan Rizali, Muhammd Ikhsan, dkk. Faktor Yang Berhubungan Dengan Pemilihan Metode Kontrasepsi Suntik di Kelurahan Mattoangin Keamatan Mariso Kota Makassar. Makassar: Fakultas Kesehatan Masyarakat Universitas Hasanuddin; 20.

Notoatmodjo, S., 2010, Metode Penelitian Kesehatan, Jakarta: Rineka.

Pramono, dan Ulfa. Analisis Faktor-faktor yang mempengaruhi Pemilihan AKDR [skripsi[. Semarang: Stikes Telogorejo; (2010).

SDKI. (2007). Survei demografi dan kesehatan Indonesia. Jakarta.

Saifuddin. 2013. Buku Panduan Praktis Pelayanan Kontrasepsi. Jakarta: Yayasan Bina Pustaka Sarwono Prawirohardjo.

Saifudin, A Bari, 2010, Panduan Praktis Pelayanan Kontrasepsi.Jakarta: Jurnal Tridasa Printer.

Sitti Afsari, (2017). Faktor Yang Mempengaruhi Akseptor Kb Dalam
Memilih Kontrasepsi. Skripsi;file:///E:/REFERENSI/sitti\%20 afsari.pdf.

Supriadi. Faktor Yang Berhubungan Dengan Penggunaan Alat Kontrasepsi Pada Pasangan Usia Subur. Jurnal ; 2017.

WHO. Maternal Mortality: World Health Organization; 2014.

Wa Ode Dita Arliana, Aryanti, Arifin Seweng, (2013). Faktor Yang Berhubungan Dengan Penggunaan Metode Kontrasepsi Hormonal Pada Akseptor Kb Di Kelurahan Pasarwajo Kecamatan Pasarwajo Kabupaten Buton Sulawesi Tenggara. Jurnal_Wa Ode, Dita Arlianan_K11109012.Pdf. Bagian Biostatistik/Kkb, Fakultas Kesehatan Masyarakat, Unhas, Makassar(Ditaode@Gmail.Com/08 5242720491).

Wawan \& Dewi M, (2010). Teori dan Pengukuran Sikap dan Perilku Manusia. Surabaya.

Yuniastuti T.A, (2011). Pengaruh Penggunaan Kontrasepsi Suntik Terhadap BB KB di Puskesmas X, skripsi, Fakultas Farmasi, Universitas Muhammadiyah Sukarta. 